\title{
МИНЕРАЛЬНЫЕ ОБРАЗОВАНИЯ НА ИСКОПАЕМЫХ ЗУБАХ ДИКОБРАЗА (ПЕЩЕРА МАХНЕВСКАЯ ЛЕДЯНАЯ, ПЕРМСКИЙ КРАЙ)
}

\author{
Т.В. ФАДЕЕВА, И.И. ЧАЙКОВСКИЙ, Е.П. ЧИРКОВА \\ Горнылй институт УрО РАН, г. Пермь
}

\begin{abstract}
Аннотация: В статье приведено описание минеральных образований на поверхностях ископаемых зубов дикобраза Hystrix brachyura и кальцитных обломках, обнаруженных в отложениях последнего межледниковья (MIS 5e) в пещере Махневская Ледяная.
\end{abstract}

Ключевые слова: межледниковье, зубы дикобраза, марганец, фосфаты.

Проблема определения геологического возраста и степени однородности палеонтологического материала актуальна в случаях переотложенных (в результате переноса материала осадочных слоев) или смешанных (роющая деятельность четвероногих хищников) зоогенных отложений. Для решения этой проблемы может быть использован тафономический анализ, в ходе которого исследуются последствия процессов, влияющих на биологический организм после его смерти (Ефремов, 1940), в том числе структурные и химические изменения. Деградация органического вещества в костях увеличивает их пористость, экзогенные элементы из вмещающей породы проникают в кость, тем самым модифицируя ее химический состав. Кроме этого, происходит адсорбция химических элементов на поверхности костей. Все эти процессы приводят к однотипным изменениям внешнего вида и внутренней структуры костных остатков, характеристики которых позволяют выявить геологически одновозрастные фаунистические комплексы позвоночных животных.

В отложениях пещеры Махневская Ледяная (Пермский край) обнаружены многочисленные костные остатки видов млекопитающих, среди которых определены виды, современные границы распространения которых расположены намного южнее (белобрюхая белозубка Crocidura leucodon (Hermann, 1780), лесная соня Dryomys nitedula (Pallas, 1778), желтогорлая мышь Apodemus flavicollis (Melchior, 1834), малайский дикобраз Hystrix brachyura Linnaeus, 1758). Кроме того, такие виды не зафиксированы в исследованных зоогенных отложениях нескольких местонахождений середины и конца позднего плейстоцена и голоцена Среднего и Северного Предуралья (Фадеева, Смирнов, 2008). Таким образом, с большой долей вероятности можно предположить, что перечисленные виды обитали на данной территории в начале позднего плейстоцена, в период последнего межледниковья (MIS 5e). Для определения геологического возраста костных остатков дикобраза использовался метод ускорительной масс-спектрометрии (AMS), в результате получена запредельная радиоуглеродная дата > 27500 лет. (АА-90664) и дата 41800 (+600, -500) лет (GrA35461)). Однако, Дж. Ван дер Плихт, руководитель радиоуглеродной лаборатории в Гронингене (Нидерланды) в комментариях к последнему результату, сообщил, что анализируемый зуб дикобраза содержал очень малое количество коллагена и полученная дата очень близка к запредельной.

В ходе раскопок 2017-2018 годов обнаружены интактные отложения в пещере Махневская Ледяная, из которых извлечены костные остатки четырех типов сохранности. В данной статье мы приводим результаты исследований IV типа сохранности, который характерен для подавляющего большинства костных остатков нижней половины зоогенных отложений. Все кости дикобраза, которые были зафиксированы в «смешанных» и интактных отложениях, отнесены к этому, самому «древнему» из выявленных типов сохранности. 
«Оксиды марганца» являются самыми характерными визуальными маркерами костей рассматриваемого типа сохранности. В подавляющем большинстве случаев это точечные минеральные образования разной степени плотности, расположенные как на поверхности костей, так и в диагенетических трещинах. На некоторых костях марганцевые образования представлены дендритными формами или темными пятнами в эмали ископаемых зубов вдоль микротрещин (рис. 1).

В подземных водах марганец обычно присутствует в виде двухвалентного (II) и при испарении воды происходит его осаждение на твердых поверхностях (Pfretzschner and Tütken, 2011). Пиролюзит (MnO2) образуется в процессе окисления гидроксида марганца при прямом контакте с кислородом (Morgan, 2005), при микробном катализе (Mandernack et al., 1995; Bargar et al., 2000, 2009). Минералы гаусманит (Mn3O4), фейткнехтит (BMnOOH) и манганит $(\gamma \mathrm{MnOOH})$ получаются в результате бактериального окисления (Mandernack et al., 1995). Бактерии Leptothrix discophora (Saratovsky et al., 2006), Bacillus sp. (Webb et al., 2005) и Pseudomonas putida (Villalobos et al., 2003) продуцируют бернессит, который впоследствии может превратиться в пиролюзит.

По результатам химических анализов, полученных на сканирующем электронном микроскопе VEGA 3 LMH с системой рентгеновского энергодисперсионного микроанализа Oxford Instruments INCA Energy 250/X-max 20, марганцевые образования на зубах характеризуются широкими вариациями состава (Mn 36,17-50,65; O 49,35-61,12; Fe 0-3,00; Ba 0-1,48 мас. \%). Примеси железа отмечены в четырех анализах из семи, бария - в одном. Высокое (больше стехиометрии) содержание кислорода позволяет предполагать принадлежность этого соединения к аморфному оксиду $\left(\mathrm{MnO}_{2} \cdot \mathrm{nH}_{2} \mathrm{O}\right)$ известному как вад или манганогель.

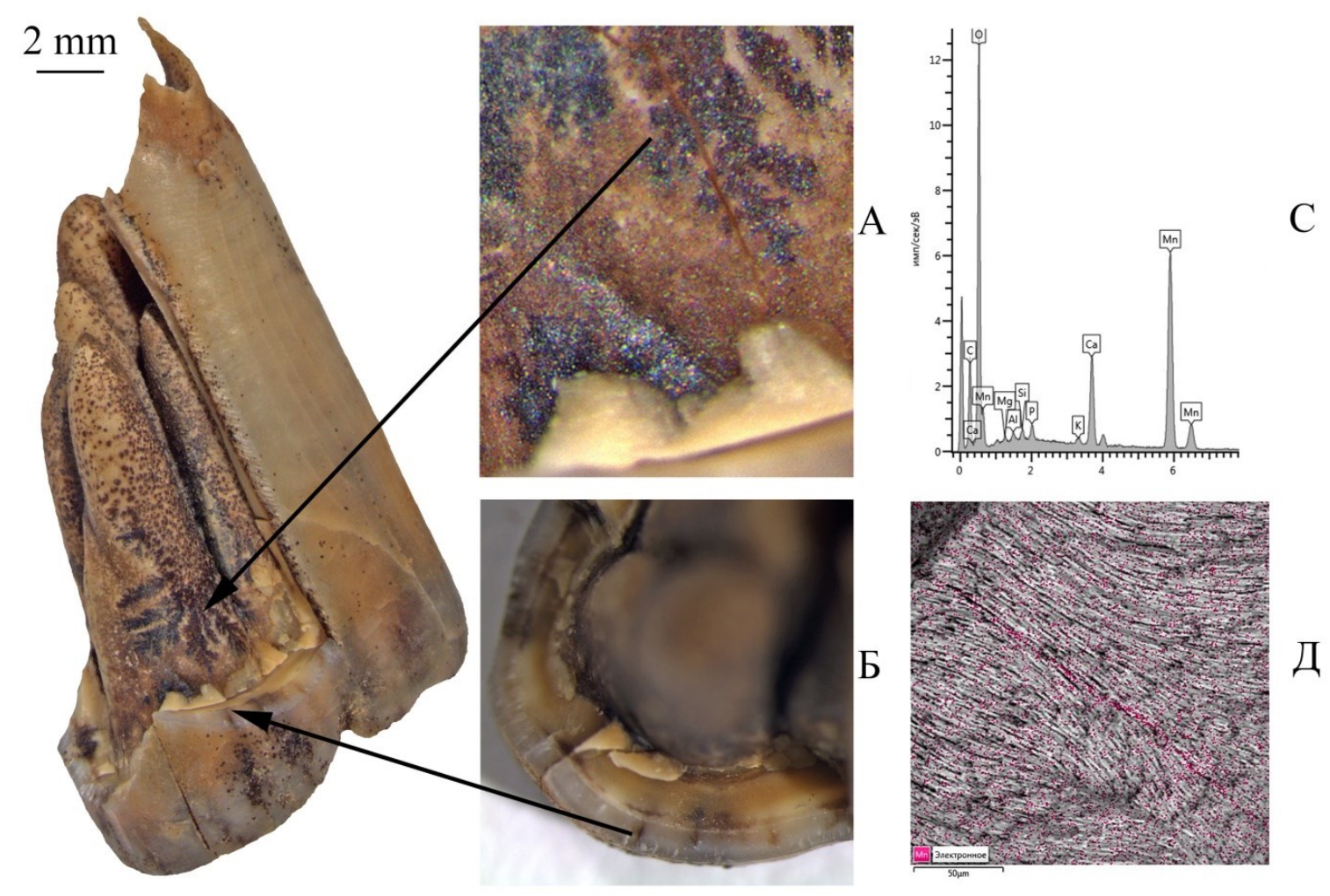

Рис. 1. Фрагмент нижнего моляра (m1-2 dex) Hystrix brachyura из «смешанных» отложений пещеры Махневская Ледяная (Пермский край). А - дедритная форма марганцевого минерала; Б - марганец в эмали зуба; C - элементный химический состав марганцевого минерала (дендрит); D - элементная карта (EDS) участка эмали зуба 
На зубах дикобраза обнаружена минеральная корка фосфатного происхождения с системой мелких трещин (рис. 2). Фосфат обнаружен и в виде плотных корок на обломках известняка (рис. 3). Корки на известняке состоят из нескольких слоев, которые однородны по химическому составу. Их количество невелико (около 1020 штук на 10 литров породы). Их происхождение вероятно связано с инфильтрацией в грунт биологических жидкостей. Обычно образование фосфатов в пещерах связывают с присутствием гуано летучих мышей или со значительным скоплением костных остатков (Hutchinson, 1950; White and Culver (Eds), 2012). Количество костных остатков летучих мышей в исследованных отложениях дальнего грота незначительно и составляет от 7 до 17 \% от общего количества идентифицированных костей мелких млекопитающих. Это свидетельствует о том, что грот использовался летучими мышами в качестве зимнего убежища, однако количество колоний было невелико. Максимальная высота этого грота в среднем около 3 метров, и зимующие летучие мыши в таких условиях легко доступны для хищных млекопитающих. Кости посткраниального скелета летучих мышей в исследованных отложениях очень немногочисленны и фрагментированы. Образование фосфатных корок на костях и кальцитах, в данном случае, вряд ли связано с экскрементным материалом летучих мышей.
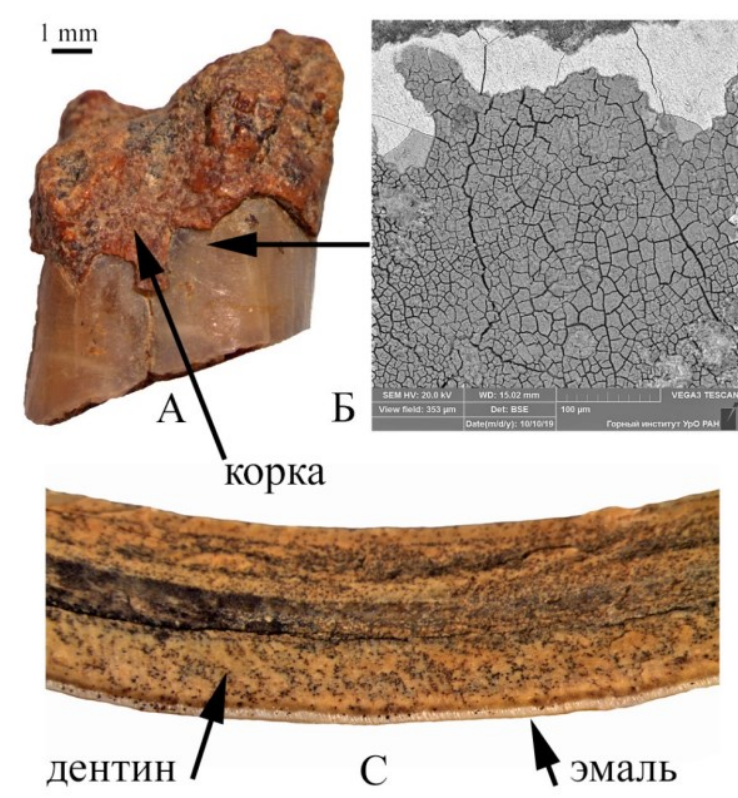

Рис. 2. А - нижний моляр (m1 dex) Hystrix brachyura c минеральной коркой;

Б - минеральная пленка на эмали моляра;

$\mathrm{C}$ - фрагмент резца Hystrix brachyura.

Пещера Махневская Ледяная (Пермский край)

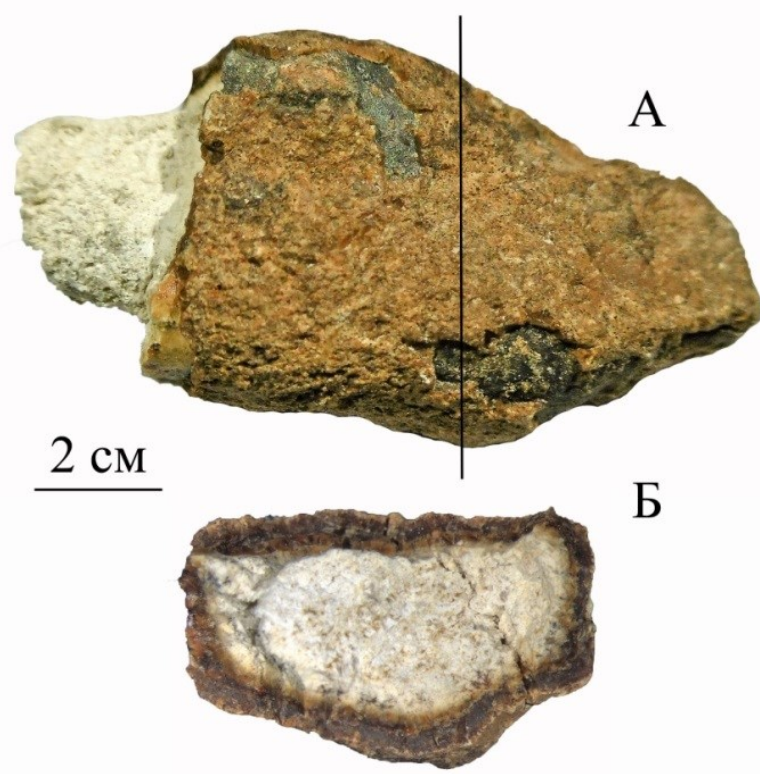

Рис. 3. Внешний вид (А) и внутреннее строение (Б) фосфатной оболочки на обломке известняка. Пещера Махневская Ледяная (Пермский край)

Среди ископаемых костных остатков крупных млекопитающих в зоогенных отложениях пещеры преобладают кости и зубы малого пещерного медведя Ursus savini. Обнаружены молочные зубы и кости новорожденных медвежат. Это указывает на то, что гибель медведей происходила во время зимней спячки и можно предположить, что образование этих минеральных корок и пленок связано с постмортальными процессами. Нельзя исключить и экскрементное происхождение фосфатов (обнаружены кости других крупных и мелких хищных млекопитающих, которые могли использовать данную пещеру в качестве временного логова). Схожие фосфатные образования были обнаружены ранее в пещере Виашерская (Пермский край), в формировании которых предпо- 
лагалось растворение костного материала пещерных медведей и отложение фосфата на карбонатном барьере путем замещения обломков известняков (Чайковский, Кадебская, 2010).

Гидроксилапатит $\left(\mathrm{Ca}_{5}\left(\mathrm{PO}_{4}\right)_{3}(\mathrm{OH})\right)$ и брушит $\left(\mathrm{CaHPO}_{4} * 2 \mathrm{H}_{2} \mathrm{O}\right)$ в списке наиболее распространенных фосфатов, встречающихся в пещерах. Брушит стабилен в слобокислой среде (ph 6) и влажных условиях, при потере воды он превращается в монетит $\left(\mathrm{CaHPO}_{4}\right)$. Уменьшение содержания органики и увеличение соотношения $\mathrm{Ca} / \mathrm{P}$ в фосфатном материале иллюстрирует минеральная последовательность брушит $\rightarrow$ витлокит $\left(\mathrm{Ca}_{9} \mathrm{Mg}\left(\mathrm{HPO}_{4}\right)\left(\mathrm{PO}_{4}\right)_{6}\right) \rightarrow$ гидроксилапатит (White and Culver (Ed), 2012).

Обработка более 50 химических анализов фосфатов позволила показать следующее. Все части зуба, пленки и корки на них, а также оболочки на обломках известняка отвечают по соотношению кальция и фосфора гидроксил-апатиту. Наиболее близкой к теоретическому составу гидроксил-апатита оказалась эмаль, характеризующаяся наиболее кристалличным строением. Далее следуют менее плотный дентин, минеральные корки на зубах и обломках известняка, а замыкает ряд тонкая трещиноватая пленка. Подобные трещины образующие тонкую сеть характерны для обезвоживающегося коллоидного вещества. Если для костей повышенное, относительно теоретического состава гидроксил-апатита, содержание кислорода может объясняться присутствием коллагена, то для минеральных образований обогащенность кислородом связывается с присутствием воды.
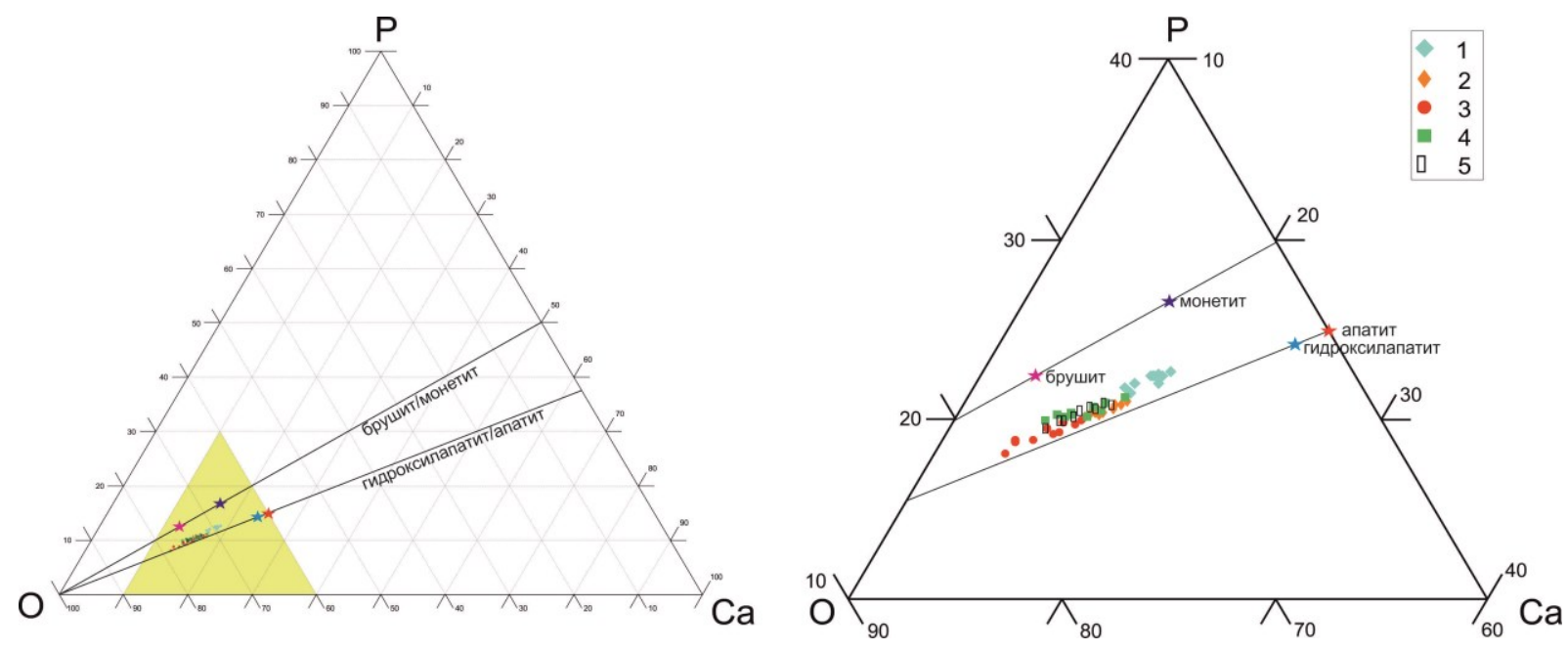

Рис. 4. Положение составов исследуемых фосфатов (атом. \%) на треугольной диаграмме:

1 - эмаль резца Hystrix brachyura , 2 - дентин резца Hystrix brachyura, 3 - пленка на эмали моляра Hystrix brachyura, 4 - корка на моляре Hystrix brachyura, 5 - фосфатная оболочка на обломках известняка. Звездочками показаны теоретические составы фосфатных минералов

Таким образом, продукты жизнедеятельности позвоночных животных и/или растворы, полученные в результате постмортальных процессов в их организмах, приводят к активной миграции фосфора в виде коллоидных растворов во вмещающие пещерные отложения. Предполагается, что состав новообразованных фосфатов (брушит-монетит или гидроксил-апатит) будет определяться не только соотношением $\mathrm{Ca} / \mathrm{P}$ в экскрементах и костном остатке, но и геохимической обстановкой в пещере расположенной среди известняков богатых кальцием, а минеральная форма оксидов марганца будет указывать на окислительно-восстановительные условия.

Исследование выполнено при финансовой поддержке РФФИ и Пермского края в рамках научного проекта № 19-44-590001. 


\title{
БИБЛИОГРАФИЧЕСКИЙ СПИСОК
}

1. Ефремов И.А. Тафономия - новая отрасль палеонтологии // Изв. АН СССР. Сер. биологическая. 1940. - № 3. - С. 405-413.

2. Фадеева Т.В., Смирнов Н.Г. Мелкие млекопитающие Пермского Предуралья в позднем плейстоцене и голоцене. - Екатеринбург: Изд-во Гощицкий, 2008. - 171 с.

3. Чайковский И.И., Кадебская О.И. Феномен постплейстоценового фосфоритообразования в Виашерской пещере // Вестн. Перм. науч. центра. -2010. - № 2. - С. 11-16.

4. Bargar J.R., Tebo B.M., Villinski J.E. In situ characterization of Mn(II) oxidation by spores of the marine Bacillus sp. strain SG-1 // Geochimica et Cosmochimica Acta. - 2000. - Vol. 64, № 16. - P. 2775-2778.

5. Bargar J.R., Fuller C.C., Marcus M.A., Brearley A.J.,.Perez De la Rosa M., Webb S.M., Caldwell W.A. Structural characterization of terrestrial microbial Mn oxides from Pinal creek, AZ // Geochimica et Cosmochimica Acta. - 2009. - V. 73, № 4. - P. 889-910.

6. White W.B., Culver D.C. Encyclopedia of Caves. - https://doi.org/10.1016/C2010-0-64793-6 - текст: электронный. - Academic Press, 2012. - 966 p.

7. Hutchinson G.E. The biogeochemistry of vertebrate excretion // Bulletin of the American Museum of Natural History. - 1950. - Vol. 96. - 554 p.

8. Mandernack K.W., Post J., Tebo B.M. Manganese mineral formation by bacterial spores of the marine Bacillus sp. Strain SG-1: evidence for the direct oxidation of Mn(II) to Mn(IV) // Geochimica et Cosmochimica Acta. - 1995. - Vol. 59, № 21. - P. 4393-4408.

9. Morgan J.J. Kinetics of reaction between $\mathrm{O} 2$ and $\mathrm{Mn}(\mathrm{II})$ species in aqueous Solutions // Geochimica et Cosmochimica Acta. - 2005. - Vol. 69, № 1. - P. 35-48.

10. Pfretzschner H.U., Tütken T. Rolling bones - Taphonomy of Jurassic dinosaur bones inferred from diagenetic microcracks and mineral infillings // Palaeogeography, Palaeoclimatology, Palaeoecology. - 2011. Vol. 310, № 1-2. - P. 117-123.

11. Saratovsky I., Wightman P.G., Pasten P.A., Gaillard J.F., Poeppelmeier K.R. Manganese oxides: parallels between abiotic and biotic structures // Journal of the American Chemical Society. - 2006. - Vol. 128., № 34 . - P. 11188-11198.

12. Villalobos M., Toner B., Bargar J., Sposito G. Characterization of manganese oxide produced by Pseudomonas putida strain MnB1 // Geochimica et Cosmochimica Acta. - 2003. - Vol. 67, № 14. - P. 2649-2662.

13. Webb S.M., Tebo B.M., Bargar J.R. Structural characterization of biogenic Mn oxides produced in seawater by the marine Bacillus sp. Strain SG-1 // American Mineralogist. - 2005. - Vol. 90, № 8-9. - P. 1342-1357.

\section{РАСЧЕТ ПЛОЩАДЕЙ ЗАКАРСТОВАННЫХ ТЕРРИТОРИЙ МУНИЦИПАЛЬНЫХ ОБРАЗОВАНИЙ ПЕРМСКОГО КРАЯ}

\author{
М.В. БОГОМАЗ \\ Горный институт УрО РАН, г. Пермь
}

\begin{abstract}
Аннотация: В Пермском крае природный карст и его антропогенные модификации распространены на территориях, сложенных породами карбонатной, сульфатной и соленосной формаций. Интенсивно карстующиеся известняки, доломиты, гипсы, ангидриты и каменная соль в регионе выходят на поверхность или залегают на небольшой глубине на площади более 30 тыс. км², что составляет 18,7\% площади края (Максимович, Горбунова, 1958). В пределах восточной окраины Восточно-Европейской платформы и прилегающей зоны Предуральского краевого прогиба закарстованы преимущественно гипсы, ангидриты, известняки, доломиты кунгурского и артинского ярусов нижнего отдела пермской системы. В современной схеме районирования закарстованных территорий Пермского края выделено шесть районов развития преимущественно гипсового и карбонатно-гипсового карста в пределах восточной окраины Восточно-Европейской платформы. Карстопроявления, как правило, приурочены к зонам разрывных нарушений и к литологическим контактам известняков и доломитов с некарстующимися породами [2]. В данной статье приводятся рассчитанные автором площади закарстованных территорий поселений муниципальных районов Пермского края.

Ключевые слова: карст, карбонатно-сульфатные породы, литологический тип, опасные геологические процессы, гипсы, Восточно-Европейская платформа, безопасность жизнедеятельности, известняки, доломиты.
\end{abstract}

Введение. Карстующиеся породы широко развиты на территории Пермского края (рис. 1). Общая площадь карстовых районов - 45,9 тыс. км², т.е. они занимают почти треть террито- 